\title{
Strategies of Developing Bilingualism in Higher Education Institution in China
}

\author{
Chunhong Zhao \\ Huanghuai University, Zhumadian, China \\ Email: zchmxy@hotmail.com
}

\begin{abstract}
Bilingual Education of Higher Education Institution in China (BEHIC) has been developed quickly in the last 10 years. However the lack of systematic theoretical and practical research hinders the development of BEHIC. In order to maintain multicultural feature in economy and politics, the strategies of developing BEHIC are to be studied in the research.
\end{abstract}

Index Terms — bilingualism, higher education institution, development, problems, strategies

\section{INTRODUCTION}

Bilingualism refers to the phenomenon of competence and communication in two languages. A bilingual individual is someone who has the ability to communicate in two languages alternately. Such an ability or psychological state in the individual has been referred to as bilinguality (Hamers and Blanc, 2000).

Bilingual education in higher education institutions in China (BEHIC) has developed quickly in the last 10 years. The status of BEHIC was approved by government policies. Different studies have been made about BEHIC, such as teaching research, subject reform, teaching assessment, teaching staff training, students ability training, teaching material development, original edition teaching material introducing and integrating. The BEHIC shows its good development momentum.

Because of the language barrier of teaching and learning in BEHIC, the arguments has been born together with bilingual education. One worry is the bilingual education may become the burden of quality and quantity control of course teaching plan; the other worry is the efficiency and operability of bilingual education. In the forum of BEHIC organized by Education Ministry in 2004, experts spoke out their worries, "the main barriers of bilingual education at present are the foreign language level of teaching staff and students, the selection of teaching material and the financial input". They pointed out that bilingual education was not language oriented and it could not be implemented solely with lowering education quality of the course.

BEHIC should be based on the educational psychology and make the balance of language study and academic study. Through the study of cognitive psychology of university students and their attitudes towards learning a foreign language, the strong desire of learning and the negative mentality coexist among the group of people who are aged from 18 to 25 . BEHIC has its special foreign language acquisition feature and complementary benefit to academic study. The study of university students' physiology and psychology shows that bilingual education based on academic study can provide effective virtual context which the traditional education cannot offer. Psychological satisfaction is a good motivation for language study and the extra benefit of language acquisition from academic study can boost the academic pursuit.

\section{THE DEVELopMENT OF BEHIC IN CHINA}

BEHIC in China is the result of economic globalization and the need of international political, cultural and economic communication. The four documents issued by Education Ministry of China mark the four development stages of BEHIC.

The first document is Several Viewpoints of Improving Teaching Quality of Higher Education (Education Ministry 2001). In the document, it says, "Education should be oriented towards modernization, the world, the future". In order to face the challenge of economic globalization and scientific and technology revolution, university education is supposed to use English and other foreign languages in teaching common required courses and academic courses, especially the biotechnology, information technology in the high-tech area and international finance and laws. In 3 years' time, 5\% to $10 \%$ of the modules should be taught in English or other foreign languages. If the condition in a university cannot offer bilingual education, some modules can be taught in Chinese language but with teaching material in foreign languages. Bilingual education should be employed gradually.

The second is Several Viewpoints on Strengthening the University Undergraduate Teaching Work (Higher Education Branch of Education Ministry 2005). In this document, it pointed that university students' ability of international communication and cooperation should be improved through the reform of College English teaching reform. Higher education institutes should make use of the reform of college English, promote the college English learning based on computer and campus internet, and develop individualized learning system to improve students' comprehensive skills in 
using English, especially listening and speaking ability.

The third document is Several Viewpoints on Deepening Undergraduate Teaching Reform and Comprehensively Improving Teaching Quality (Education Ministry 2007). It pointed, "Encourage bilingual education, introducing foreign scholars and experts to take bilingual teaching work in academic modules. Encourage and support overseas graduates to teach academic module in English. Therefore the specialized English level and ability of students should be improved.

The fourth document is Evaluation Index System of Undergraduate Teaching Work in General Institutes of Higher Education (Education Ministry 2007). A: Motivation measures and policies made for bilingual education; The ratio of bilingual-taught modules over the whole course modules is equals or over 10\%, especially in the field of biotechnology, information technology, finance and laws; Implement bilingual education in other courses actively. B: Emphasis on bilingual education; the ratio reaches a certain standard. Bilingual education is defined as "A teaching model of using a foreign language other than mother language in teaching non-language modules directly and acquiring a foreign language and academic knowledge simultaneously". The exact ration is declared as Bilingual-taught module refers to using teaching material in a foreign language and the total contact hours taught in a foreign language is no less than $50 \%$ (Language course is not included in the range of bilingual-taught module).

As for the promotion of Education Ministry of China, bilingual education sprung up rapidly in higher education institution. Many universities get strong support in training teaching staff, equipping teaching facilities in bilingual education. More and more universities have been promoting the bilingual education and great progress is made in the discipline of economy, law and medicine. Independent curriculum was made in the field of international economy and trading.

Many measures are implemented to carry out BEHIC. For the teaching plan, in the Year 1, intensive English language training modules are open besides foundation modules. In the following schooling years, some of the academic foundation modules and academic core modules are taught in 100\% English of 50\% English with English teaching material and PPT. 3-5 foreign experts are invited to teach some of the core modules. Opportunities of exchange study overseas of internship for one or two semesters can be offered for undergraduates with the cooperation with higher institutions and companies abroad. The credits earned abroad are part of the total credits that should be earned to get a degree certificate. The thesis should be written and defending in English. Some courses with plenty of overseas student are taught in English only. According to the statistics, The number of National Model Bilingual Courses is 97 in 2007, 100 in 2008, 152 in 2009 and 151 in 2010.

\section{THE PROBLEMS OF BEHIC}

Although there is great progress of bilingual education in higher education institutes in China, many problems still hinder the development of bilingual education in China.

\section{A. Insufficient Theoretical and Practical Research}

Bilingual education involves in pedagogy, sociology, linguistics, psychology, sociology and politics. Only the methodology research is far enough to meet with the demand of bilingual education development. Some universities just follow the policy of government without deep research or considering the effect of bilingual education. It is necessary to build up systematic research system from government to teaching staff. Special research institution should be set up to make study of BEHIC so as to guide the practice of BEHIC.

\section{B. Insufficient Essential Contribution of Bilingual Education}

UNESCO has made a format of teaching quality assessment, teaching quality $=$ (students + teaching material + environment + teaching methodology)*teaching staff. The entire five elements that contribute to teaching quality of bilingual education have their problems.

1. The serious insufficient teaching staff

The insufficiency of teaching staff restricts the development of bilingual education in higher education institution in China. The resources pool of bilingual teaching staff is limited. One is the English language teacher who goes for further education in some specialty; the other is academic teacher with proficient foreign language skills. The problems are English language teachers' knowledge of specialty is nor broad and deep enough and academic teacher's spoken and listening skills are not good enough to communicate in the foreign language freely. Neither can satisfy the bilingual teaching fully. The introducing of foreign experts can help with the bilingual education. But in most cases the real expert cannot stay long in China to teach one or two semesters, much less the academic research.

2. The choice of teaching material

There are 4 general ways of choosing teaching material and each has its limits. The first is original edition (gravure). It is difficult for undergraduates and the price is usually much higher than the local books of the same kind. The second is self-edited, which is students-oriented and changes with the time, but lack of authentic language expression. The third is using Chinese edition teaching material and English PPT, of which the shortcoming is obvious that students will not even have material to read as reference in the target language. The fourth is the translated materials. The translation level itself is a problem

3. The students' receptivity 
Bilingual education requires students' English language skills and the ability of expressing academic knowledge in English. Students' English level is different. Only a few students can use English freely to express themselves. Thus the results of bilingual education are not encouraging and students lose their confidence gradually.

4. Study environment

Both in-class and outside class environment is poor. The size of class is one of the vital problems of university education. The normal size is more than 100 students in one class. It is very hard to have face-to-face discussion, presentation or the other ways to deliver the bilingual modules efficiently. The outside class environment for bilingual education is very limit. No legal status for bilingual BEHIC although the ministry of education issued several documents of viewpoints for BEHIC. The foundation of bilingual education in elementary and middle-school period has not paved a smooth way for university bilingual education.

5. Limit teaching methodology of BEHIC

Besides the introduction of some teaching methodologies of bilingual education abroad, there is little study of teaching methodology of BEHIC. Bilingual education in different countries and cases should be analyzed and local feature of BEHIC should be considered into the efficient delivery during teaching and learning.

\section{THE STRATEGIES OF RESEARCH TO IMPROVE THE BEHIC}

The recognition of bilingualism as a social, individual and linguistic phenomenon has several implications for educational practice. In order to solve the problems and improve the BEHIC, the following research needs to be done.

To begin with, teachers have to appreciate the sociolinguistic circumstances surrounding the development of bilingual competencies in their students. If they are in positions of power and influence, they could try to propose to their governments or institutions educational models appropriate for their circumstances. A first task is therefore to understand the sociolinguistic situation in their particular society or community as well as to identify the assumptions behind any bilingual education model.

Secondly, a survey of the literature also makes apparent that each community is not exactly the same. Although lessons can be learned from understanding another community, a model that may work for one community may not work for another. The earlier the teacher realizes this, the more realistic he or she can be. If the teacher is not in a position to influence the model of bilingual education imposed on the classroom, he or she can still try to see what positive attitudes towards bilingualism can be encouraged in the learners. For a start, he or she must realize that demands may be placed on the bilingual ethnic minority child and must be sensitive to cross cultural identity issues. If the teacher can try to foster cross cultural openness and learn to become bicultural—if not bilingual—it will provide some motivation to learners. Every effort, no matter how small, to learn the learner's language is usually appreciated. Rather than presenting the learning of two languages as onerous, the teacher can also point out to students the advantages of knowing more than one language and design tasks to enable them to appreciate such enrichment opportunities in their environment. If the teacher is bilingual, It may also be useful to recount to students his or her experience of becoming bilingual. This, in turn, will give rise to opportunities for learners to share their experiences as well. With a positive attitude towards bilingualism, the teacher and learners can then work together to enable the learners to make appropriate language choices for different situations as well as observe the nuances in mixed mode interaction.

Thirdly, appropriate incentive system and teaching staff training of bilingual education should be set up. Teaching bilingual course needs more time to prepare for it and the fluent language skills needs more exposure to language environment. Extra financial payment should be made for bilingual teaching staff themselves and the training in home or abroad universities to improve their professional quality.

Fourthly, appropriate bilingual teaching material should be chosen or developed. Original foreign teaching material should be selected from the publishing products. Essential and difficult points should be annotated in Chinese and specialized vocabulary should be made as appendix. Some good books edited or co-edited by Sino-foreign experts or Chinese experts solely can be chosen as bilingual course as well (Yin Hou, 2008) Students should get involved in teaching material selecting and developing to arouse their interest in the subject. Students can have more to say whether the books suit their academic needs and language level or not. Teaching staff's responsibility is to find the efficient and effective way in how to deliver and organize the information.

Fifthly, appropriate assessment system and teaching methodologies of students learning should be studied. Because of the difference background of students' foreign language and academic level, the ratio of using a foreign language in class should be geared by students' foreign language level and ability of receptivity. More work like knowing students degree of recognition and receptivity should be done through tests, talking and net answer system. As for the essential and difficult points, teacher should use Chinese to repeat and emphasize it to make sure the right understanding of the knowledge. Assessment system should be borrowed and developed from the successful experience of the other countries.

\section{CONCLUSION}

The multifaceted nature of the phenomenon of bilingualism needs to be fully appreciated for any pedagogical 
programme designed to foster bilingual development to succeed. To study bilingualism is to study the interaction between linguistics, psycholinguistics, sociolinguistics, pedagogy and the real world of language politics and policy. To be able to appreciate such interactions in changing times and adjust classroom practice in the light of changes is the hallmark of a professional language teacher.

\section{REFERENCES}

[1] Education Ministry. (2001).Several Viewpoints of Improving Teaching Quality of Higher Education. http://www.scfai.edu.cn/JxzlDetail.aspx?Id=20 (accessed 08/06/2011).

[2] Education Ministry. (2007). Several Viewpoints on Deepening Undergraduate Teaching Reform and Comprehensively Improving Teaching Quality. http://www.jyb.cn/cm/jycm/beijing/jybgb/gdjy/t20070525_86087.htm (accessed 08/06/2011).

[3] Education Ministry. (2007). Evaluation Index System of Undergraduate Teaching Work in General Institutes of Higher Education. http://www.gdmb.gov.cn/2011/0314/127.html (accessed 08/06/2011).

[4] Hammer and Blanc. (2000). Bilinguality and Bilingualism (Second Edition). Trumpington Street, Cambridge: Cambridge University Press.

[5] Higher Education Branch of Education Ministry. (2005). Several Viewpoints on Strengthening the University Undergraduate Teaching Work. http://www.nwnu.edu.cn/Article.do?id=849 (accessed 08/06/2011).

[6] Hou Yin, (2007). Karasen's Theory and Bilingual Education in University. Journal of Shenyang Normal University (Social Science), 31, 156-157.

[7] Ke Jinyun. (2007). Bilingualism and Bilingual Education: A Review of Development Abroad. Journal of Tianjin Normal University (Elementary Education Edition), 8, 120-121.

[8] Paulston. (1988). International Handbook of Bilingualism and Bilingual Education. New York: Greenwood Press.

[9] Zhang Hongxia, Li Ping. (2009). On the Implementation of Bilingual Education in the Specialty of National Economy and Trade. Shandong Science and Technology University Journal, 25, 88-90.

Chunhong Zhao was born in Zhumadian, China in 1977. She received her M.A. degree in English Language and Literature Henan University, China in 2006.

She is currently a lecturer in International College, Huanghuai University, Zhumadian, China. Her research interests include Bilingualism and Sino-Foreign Education Cooperation. 